\title{
Community Members' Knowledge, Support and Perceived Benefits of Land Reform in Rural South Africa: The Case of Mtunzini, in the KwaZulu Natal Province
}

\author{
J. Guambe 1 \\ K.D. $\lg e^{2}$ \\ 1, 2 Department of Sociology, University of Zululand, P/bag X1001, KwaDlangezwa, 3886, South Africa \\ jeremiaguambe@webmail.co.za1,;igedavies@gmail.com²
}

\section{Doi:10.5901/mjss.2014.v5n8p586}

\begin{abstract}
South Africa's post-apartheid land reform programme was largely influenced by the World Bank's 'Willing-Seller Willing-Buyer' or 'Negotiated Land Reform Approach'. Past studies have been dealing with land reform within the ambits of poverty reduction, violence and human rights. This study investigated the perception of the people at grass root level about land reform, within the participatory paradigm. In a survey of community members in rural Mtunzini ( $(n=66)$ the study sought to decipher the levels of knowledge, support and perceived benefits of land reform among farmers and agricultural workers. Scale construction was conducted using Principal Components Analysis and hypotheses were tested using bivariate correlation. The results of the study showed that community members' knowledge of land reform predicts their support for land reform. The result further showed that support for land reform is dependent upon the perceived expected benefit from the program. The results of the study also showed that the public perceived the power of chiefs as having potential in processes of land distribution. This is due to the fact that traditional leaders are leadership structures in closer communication with the people, especially in the rural areas. The study further demonstrated that distributing land without reasonable financial support to land reform beneficiaries will not be helpful. On the basis of these findings it was recommended that transparent mass education of the populace especially in the rural areas about land reform, and land policy will increase popular support and generate positive attitudes from the population towards government programmes.
\end{abstract}

Keywords: Willing Seller -Willing Buyer; Restitution; Apartheid; Service delivery.

\section{Introduction}

The land reform programme in South Africa was designed to redress the challenges that are the results of the past experienced by the people, especially African people. In line with the international practices therefore, the South African land reform policy must aligns with the needs of the people who are landless; thus the government needs to communicate with the society especially on the rural areas about the land reform. Land is a complete resource upon which people are dependent on for food, shelter, and clothing as well as the spiritual well-being of the community. In fact (Bhengu, 1995:15) argued that all human beings should have access to land in order to satisfy their human needs. The land problem in South Africa dates to the earliest colonial times, when native lands were expropriated from their rightful owners - often without compensation (Tupy, 2006). While the land reform policy officially aims to reach a range of beneficiaries including women, young people, the unemployed, farm workers and aspirant commercial farmers there has been a discernible shift in policy in favour of the latter group in recent years (Lahiff, 2007). Contemporary development scholars have been advocating the inclusion of people's participation in development projects as they believe the avowed objectives of any project cannot be fully achieved unless people meaningfully participate (Mohammad, 2010:1). The people at the grass root are the ones the policy is applied to and they are the ones who can bring social change and development in the society (Mohammad, 2010:1). The study also proposed to determine whether people, especially farmers, at the rural areas have basic knowledge of land reform and if this knowledge leads to support for land reform and the perceived benefits of their programme. According to Bhengu (1999) the history provides the necessary facts on how communities were side-lined and disadvantaged by colonization.

\section{The Origins of 'Separate Development' in South Africa: The Independent Bantu Stans}

Lipton (1972) states that the policy of separate development served as a structural solution for apartheid's planners, who 
wanted to turn South Africa into a white republic in which Blacks did not feature as citizens. This 'Bantustan' policy sought to assign every Black African to a 'homeland' according to their ethnic identity. Coles (1993) argues that land policies associated with apartheid shaped the most basic areas of life for all South Africans, and resulted most significantly in widespread dispossession of land for non-whites. The African reserves, which provided the territorial base for the Bantustans, comprised (56-4 square miles), which is 12 per cent of the area of South Africa. In addition to the quota of land to which Africans are still entitled under the 1913 and 1936 Land Acts, they will constitute 13.7 per cent of the area. The African reserves are spread round South Africa in a fragmented horse- shoe comprising eighty-one large and 200 smaller blocks of land. Each of the proposed states would house their de facto population and those members of its tribe now in 'white' South Africa, the de jure population. The land is the issue is the one on which the Bantustan leaders have expressed themselves strongly.

\subsection{Access to Land and the Rights Discourse}

Hamilton (2006) argued that the poor delivery on land reform in post-apartheid South Africa is best explained through a close analysis of the form and content of the constitution of 1996, because the constitution conceives of the goals and means of land reform. Thus every land claim has a protracted legal adjudication of two competing individual rights: the existing right of ownership versus a prior right of ownership or the right of access to land (Hamilton, 2006: 139). Language and practice of rights has emerged out of differential privileges or access to goods, benefits or power dependent on an individual's class, sex, or race. Rights discourse and associated institutions and practices therefore tend to belabor rather than aid the process of redressing historical wrong, especially in a place like South Africa where inequalities and historical distortions are so marked. The question of land reform is better understood if articulated in terms of need and its conception of history and politics (Hamilton, 2006: 142-143).

\subsection{The right to land and the notion of Basic Human Needs}

Galtung (1980:59) argue that "a need should be distinguished from a want, a wish, a desire, a demand". Basic human needs are psychologically determined while wants are socially determined (Burton 1990:95). The 'need' refers to necessities for not only biological survival but also for the health and development (physical and mental growth) of persons as human beings (Coate \& Rosati, 1988:3). Burton (2001) argues that reference is usually made to needs such as identity, recognition and security; the latter understood not simply as physical security but rather security of the other needs. Marker (2003) has identified nine basic needs that are accepted within the needs theorists' community. These needs are the need for safety and security, the need for belongingness and love, self-esteem, personal fulfillment, identity, cultural security, freedom, distributive justice, and the need for participation. All individuals have needs that they strive to satisfy, either by using the system or acting as a reformist or revolutionary. Given this condition, social systems must be responsive to individual needs, or be subject to instability and forced change (possibly through violence or conflict" (Coate \& Rosati, 1988).

\subsection{Market Based Land Reform (MBLR): Challenges to successful implementation}

In South Africa, the debate around land reform since 1994 has focused on the specific concept of 'willing seller, willing buyer' (WSWB), rather than the wider category of MBLR (Lahiff, 2005). Willing Seller Willing Buyer has some history of usage in South Africa, particularly around the continuing operation of the Expropriation Act 63 of 1975. In this context of expropriation, Willing Seller Willing Buyer refers to an imaginary ideal rather than an actual practice. Willing Seller Willing Buyer entered the discourse around land reform in South Africa gradually during the period 1993-1996, reflecting the shift in economic thinking of the ANC from left-nationalist to neo-liberal. It was absent from the ANC's 'Ready to Govern' and Reconstruction and Development Programme (RDP) in 1994 when the ANC took power (World Bank, 1994; Hall, Jacobs \& Lahiff, 2003). The major concern of the South African government is to change the distribution of land (Lewin \&Weiner, 1997) that is based on races. The Willing Seller Willing Buyer requires that the government shall pay compensation to the land owner that is market-related (Lahiff 2005). Hall (2007) argues that the land acquisition grants were too small, forcing groups of poor households who qualified for them to pool their grants together to buy farms being offered on the market. Kepe \& Cousins (2002) have argued that, poor planning, and lack of government support, most of the land on these purchased group farms remained underutilized. Lahiff (2007) has also argued that most of the good quality land is sold by public auction or private transactions and thus not available to poor land reform beneficiaries. Hall (2007) points that the focus on elite Black farmers limits the impact of land reform for the greater majority of landless 
people. Fraser (2007) is of the view that the element of land reform in the context of South Africa is the government taking white-owned farms. Some farmers sell under compensation, while others refuse to sell. This is allowed by the Willing Buyer Willing Seller approach.. The decision to selling or refusing is rooted in the strong bond of the farmers to the land and identifies material and symbolic reasons influencing deciding.

The MLRA requires that landowners should come forward to sell after the price had been offered, and without political involvement (Borras, 2005). In some cases, the white farmers are motivated by material interests where the Willing Seller Willing Buyer, is attractive enough to increase number of sellers (Massey, 1997). According Fraser (2007) many of the white farmer's decision not to sell stemmed from their material and symbolic interests in the land. Fraser (2007) also argues that the monetary payments as compensation did not attract sufficient numbers to sell. Bernstein (2002) argued that the development of the rural South Africa have influenced some of the white landlords to sell the land. Fraser (2007) also asserts that there are also contributions made by white farmers, assisting beneficiaries after the transfer of land. Lahiff (2005) states that it is clear that white farmers are the major role players in the slow pace of land reform, but specific reasons not to sell are unknown. Fraser (2007) noted that white farmers agree to sell their farms on the conditions that they will be partners or mentors to the land reform beneficiaries.

\subsection{Capacitating Beneficiaries}

Rural resources play an important role in the survival strategies of a significant number of households. Thus land reform can play a role in extending the area from which such households can draw their resources. But a more effective land reform programme than the one that has been implemented so far must recognize the complexity and diversity that exists in rural areas. There are economic costs to redistributing land to people who do not want to or are unable to utilize the land effectively. According to Schirmer (2010) the second aim of a new, more realistic land reform programme must be to enhance the capacity of land reform beneficiaries in viable agricultural areas. Local markets and local job opportunities can be built up by strengthening existing programmes like the Spatial Development Initiatives, the Public Works Programme, and the promotion of rural small, medium and micro enterprises. These programmes should then all be implemented simultaneously in areas where land reform beneficiaries are willing to undertake part time work. By gaining access to a non-agricultural income while maintaining an interest in agriculture such beneficiaries would invest parts of their income into improving their farms while selling various products to the workers and administrator s brought into their areas by the government programmes. It must be recognized that such initiatives will only benefit a small minority of rural blacks. With this reality in mind the policy makers behind land reform should develop a separate strategy aimed at making a small difference in the welfare of the average rural person. This can be done by allowing individuals and communities who want to access more agricultural land to do so, as well as by allowing those who want residential land in areas close to a road or a town to benefit from land reform. These processes should largely be driven from below and the job of land reform officials should be to inform rural people about the programmes, to make the programmes accessible to poor, illiterate people and to minimize the impact of the programme on valuable agricultural land. Such a multi-pronged framework would, in my opinion, have a far better chance of making a real difference in the lives of rural people than the previous programme in which land reform was transferred to 'communities ' in the hope that despite their poverty and the absence of both information and markets they would become successful agricultural producers (Schirmer, 2010).

\subsection{Land Reform, Rural development and Agricultural Development}

According to Greenberg (2002) significant failure in most analyses of the land reform process in South Africa to date has been the artificial separation of agricultural restructuring and land reform. The land reform programme has been treated as if it has a separate and coherent logic in and of itself. If land reform is not considered in conjunction with agricultural reorganization, embedded in the broader process of political democratization and economic restructuring, it becomes very difficult to make sense of the developments in the rural polity and economy since 1994 (Greenberg, 2002:42). South Africa's macro-policy emerges from a strategic perspective that emphasizes urban job creation as the key development task facing the state. The National Spatial Development Perspective (NSDP) (Office of the President, 2006) is the most explicit articulation of this vision, which fits precisely into the World Bank's current theoretical framework (World Bank, 2009). The new National Planning Commission's Medium- Term Strategic Framework (MTSF), which applies to the government as a whole, states that the NSDP will be reviewed and, where appropriate, adjusted, but does not go any further (National Planning Commission, 2009). There are opportunities for gains by the rural poor, while recognizing that as long as the rural poor and the marginalized remain disorganized and unable to drive change in the rural areas through 
their own activity, it is unlikely that grand plans will be realized (Greenberg, 2010).

Concerns have been raised about giving the old Department of Land Affairs (DLA), which patently failed to carry out its mandate of delivering land reform, additional tasks. The weak DLA is being given the enormous and complex task (with few extra resources or staff) of coordinating rural development across three spheres of government, as well as delivering on land reform (Pienaar, 2009). A primary focus is on using natural resources as the basis for economic development, and on people taking control over their own destiny (Ministry for Rural Development and Land Reform, 2009). For the first time, the actual base of beneficiaries is clearly identified. It is also useful that Department of Rural Development and Land Reform is moving beyond a one-size-fits-all approach to land reform and agricultural support (Greenberg, 2010). However, it is not clear where the majority of the existing beneficiaries of the land redistribution and restitution programmes fit. They are people with secure access to land, but with limited resources of their own, and often without deep agricultural skills. The critical role of local government in coordinating and facilitating activities at local level is entrenched as part of the discourse of the state. However, it is coming under question from both outside the state, as citizens lose faith in the state's ability to deliver on its promises (Powell, 2009), and from inside the party-state (Carrim, 2009). A restructuring of local government will be driven by the broader perspective of what development is and how it is anticipated that it will unfold. In this context, it appears that the DRDLR is moving to occupy the jurisdiction of local government, by playing an interventionist and coordinating role in development at the local level (Pienaar, 2009).

\subsection{Knowledge about the land Reform}

According to Holden (2008), the knowledge of land reform contributes in the process of land distribution especially in the rural areas where landlessness is severe and that the laws shall be clear to the rural people. When people had enough knowledge about the law it will create the ability to differentiate between traditional norms and the behaviour of the people. If the law had been properly stated and clearly understood, it will change the behaviour of the people through interpretation. Many changes have been made in the federal and regional land proclamations and regulations (Holden, 2008). It could be concluded that the knowledge of the law is poor; this according to Holden (2008) could be caused by illiteracy, not participating in meetings and the mismanagement of the administrations. On the situation of the low knowledge of the people about land reform, people are able to make opinions that could be assessed whether they are in line or not with the law. Holden (2008) argued that changing male dominance in the household is difficult to change because it is embedded within the customs and the legal support is the major requirement for women empowerment and joint titling of land. In the existence of traditions, laws that are not enforced will never help especially when competing with strong traditions against them.

\section{The Present Study}

Most of the studies on the land issue had been dealing with land reform within the ambits of poverty reduction, violence and human rights. While these perspectives have been beneficial, there has been little emphasis on the perceptions and attitudes of the people towards the land reform process. The perceptions and attitudes are important because they often serve as a precursor for public support for land reform process. Consequently therefore, this study aimed at uncovering the level of knowledge of the land reform process as well as the attitudes and perceptions of the people at the grassroots level towards land reform. These perceptions are important in order to determine whether people at grass root perceive redistribution of land as presently conducted to serve political interests or to reduce inequality amongst people. The study also proposed to determine whether people, especially farmers, at the rural areas have basic knowledge of land reform and if this knowledge leads to support for land reform and the perceived benefits of their programme

Many of the studies had been concentrating on land reform from the basis of poverty reduction, violence and human rights, therefore this study aimed at investigating whether demographic factors account to knowledge, support and perceived benefits about land reform and also to investigate whether there is the relationship between knowledge and support to land reform.

Since the demise of the apartheid regime in South Africa, land reform has been one of the most contentious issues. The issue of the return of land to the origin majority black populations has therefore attracted great attention among scholars as well as policy makers. It is as a result of this that the present study proposed to unravel the possibilities of a participatory dimension to the land question which to a large extent has been missing from the current institutional and policy framework, and may have been responsible for the spate of unrest among the populace. The present study therefore generates valuable data on lay knowledge and support for the land reform process in South Africa. Such information will help policy makers understand the dynamics of public support and expected benefits from 
the land programme. It also underscores the importance of programme information dissemination and its key role in generating popular support.

In line with the aforementioned objectives, it was therefore hypothesized as follows:

H1: There is correlation between demographic factors and knowledge about land reform.

H2: There is correlation between demographic factors and support to land reform.

H3: There is correlation between demographic factors and perceived benefits to land reform.

H4: Knowledge about land reform is correlated with support to land reform.

H5: Support to land reform is correlated with perceived benefits of land reform.

H6: Knowledge about land reform is correlated with perceived benefits of land reform.

\section{Research Methods}

The study adopted a quantitative research approach, using the survey design. This research strategy entailing the likert scale type questionnaire has been widely utilized in recent attitudinal studies within the participative paradigm (See for example; Mupambwa et al., 2012). The sampling procedure adopted in the study was a compromise between technical efficiency, nature of the terrain and time available. According to Statistics South Africa (2013) the population of Mtunzini was estimated to 2000 people, with the surrounding areas that are regarded as traditional authorities (Brinkhoff, 2013). Using the Raosoft sample size calculator ( (@ http://www.raosoft.com/samplesize.html), based on the estimated population of Mtunzini, at a standard error margin of $10 \%$, a confidence level of $90 \%$, and a $50 \%$ response distribution, a sample size of 66 was electronically calculated. The total sample for the study was therefore 66 respondents $(n=66)$. Data was collected using a structured likert scale questionnaire. Scales and subscales were constructed using Principal Components Analysis (PCA). Scale KMOs. BTS, means and Standard Deviation are reported. Furthermore, Relationships between variables were discerned using bivariate correlation.

\subsection{Scales and Measures}

\subsubsection{Knowledge about land reform (KNOWLAND)}

The study aimed to determine the level of knowledge that the people have about land reform. A variable known as KNOWLAND was computed electronically through PCA from a list of five items derived from the questionnaire for the study. The PCA revealed KMO $=.680, \mathrm{BTS}, \mathrm{X} 2=108.785,(\mathrm{df}=36), \mathrm{p}<0.05$ indicating that the sample was adequate for factor reduction. PCA extracted only one factor named KNOWLAND, which accounts for $31.760 \%$ of variance (shown in table 5.10). Other factors become irrelevant for extraction purposes after the variable KNOWLAND has been extracted. As can be deduced the most import item in the describing KNOWLAND is ' am familiar with legislation related to land reform in South Africa', mean=3.05, SD =1.087.

\subsubsection{Support for land reform (SUPPOLAR)}

The study also sought to find out the support people have about land reform. A variable known as SUPPOLAR was computed electronically through PCA from a list of five items. The PCA revealed KMO $=.625, \mathrm{BTS}, \mathrm{X} 2=169.612$, (df $=$ 55), $p<0.05$ indicating that the sample was at least adequate for factor reduction. PCA extracted only one factor named SUPPOLAR, which accounts for $27.784 \%$ of variance. Other factors become irrelevant for extraction purposes once the variable SUPPOLAR has been extracted. As can be deduced from the table 13 the most import item for SUPPORLAR is the statement; 'land legislation must strengthen the power of chiefs on land', mean=3.11, SD=1.314. Fig 2 shows the scree plot distribution of SUPPORLAR which reflects that other factors become irrelevant in extraction once the variable SUPPORLAR is extracted.

\subsubsection{Perceived benefits to land reform (PERBEN)}

The study also sought to find out the opinions about land reform. A variable known as PERBERN was computed electronically through PCA from a list of five items on the questionnaire. The PCA revealed KMO $=.808, \mathrm{BTS}, \mathrm{X} 2=$ 231.278, $(\mathrm{df}=66), \mathrm{p}<0.05$ indicating that the sample was at least adequate for factor reduction. PCA extracted only one factor named PERBERN, which accounts for $37.212 \%$ of variance. The scree plot depicts that other factors becomes irrelevant for extraction purposes once the variable PERBERN has been extracted. As can be deduced from the 
descriptive statistics that the most import item for PERBERN is the item the success of land reform will make black people feel the sense of repatriation', mean=3.14, SD=1.201. Other factors become irrelevant in extraction once the variable PERBERN is extracted.

\section{Results}

\subsection{Determinants of Lay Knowledge about Land Reform (KNOWLAND)}

KNOWLAND seeks to investigate the knowledge the community of Mtunzini has about land reform. This is important in the study because the knowledge the people have about land reform is expected to lead their support for the programme. The result of PCA for KNOWLAND and process of scale construction is discussed here forth.

Table 1: Zero-order correlations for KNOWLAND and demographics

\begin{tabular}{lllllllll}
\hline & 1 & 2 & 3 & 4 & 5 & 6 & 7 & 8 \\
(1)Gender & & & & & & & & \\
(2)Race & & & & & & & & \\
(3)Age & & & & & & & & \\
(4)Manital status \\
(5)Number of wives \\
(6) Religion \\
(7) Employment
\end{tabular}

The results on Table 1 show that social demographic factors are correlated with knowledge about land reform. Results shows that gender is correlated with KNOWLAND, $r=.245, p<0.05$ (2 tailed), age, $r=.330, p<0.05$ (2 tailed). The results further showed that KNOWLAND is correlated with marital status, $r=.225, p<0.05$ (2 tailed) religion, $r=-.254, p<0.05$ (1 tailed), education, $r=-.384 p<0.05$ ( 1 tailed) which means. The relationships between KNOWLAND and all other social demographic variables fell below the points of statistical significance. This supports the argument by (Rugege, 2004) that being impoverished of the Black people is the product that is based on the history of colonisation. In a study from the Northern Cape province (Tilley, 2004) identified a perception among landowners that both land reform applicants and the DLA were 'unreliable' negotiating partners as because they do not have autonomy to engage in negotiations on their own behalf and remain dependent on officials to determine the ultimate grant amount and to finalise the transaction because of the DLA's protracted procedures, negotiating style and phased project cycle' (Tilley, 2004:38).

\subsection{Determinants of Popular support for Land Reform (SUPPOLAR)}

Hamilton (2006) argued that the poor delivery on land reform in post-apartheid South Africa is best explained through a close analysis of the form and content of the constitution of 1996. Thus every land claim involves an extended legal adjudication of two competing individual rights: the existing right of ownership versus a prior right of ownership or the right of access to land (Hamilton, 2006: 139). According to Thwala (2001), the main objective of land reform must be to bring a just and equitable transformation of land rights in South Africa. This objective has a number of dimensions. Firstly, land reform must address the gross inequality in landholding. Secondly, it must provide sustainable livelihoods in ways that contribute to the development of dynamic rural economies. Thirdly, particular attention must be given to the needs of marginalized groups, especially women, in order to overcome past and present discrimination. Fourthly, rural people themselves must participate fully in the design and implementation of land reform policies Thwala (2001) and this study argue that demographic factors lead to support of land reform.

Table 2: Zero-order correlations for SUPPOLAR and demographics

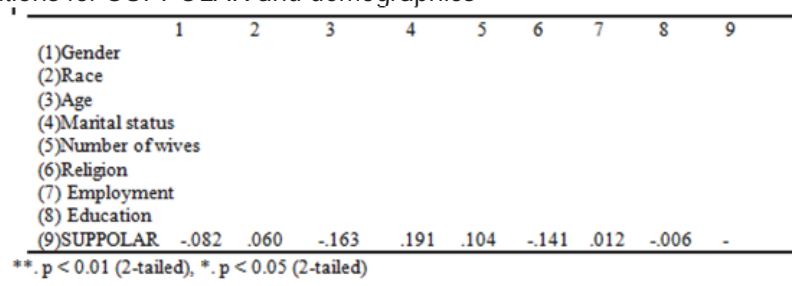


The results from the study (see table 2) shows that there was no correlation between demographic factors and support to land reform gender, $r=-082, p=0.05$, race $=.060, p=0.05$, age, $r=.163, p=0.05$. Mohammad (2010) outline that the inclusion of people's participation in development projects as they believe the avowed objectives of any project cannot be fully achieved unless people meaningfully participate in it (Mohammad, 2010:1). The people at the grass root level are the ones who experience the effects of landless on daily basis. Consideration of views of the people at grass root level is very important because such people know what type activities to utilize land on for their human needs. These interests may be agricultural, spiritual or economical, thus the views of the people enhance interrelationship between the people themselves in the society (Mohammad, 2010:1).

\subsection{Determinants of Perceived Benefits of Land Reform (PERBEN)}

Participation development approach offers opportunities to share the methods for strengthening participation across boundaries so that, for instance, those who have been endorsing participatory planning can learn lessons about patronage or human rights education, and those who have developed participatory methods for consultation, planning and observing are able to connect them to the new governance programme (Lister, 1998).

Table 3: Zero-order correlations for PERBEN and demographics

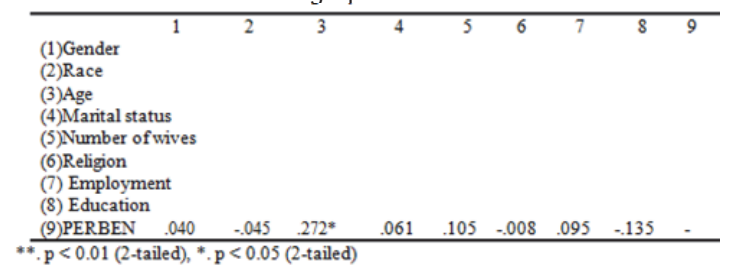

The results of the study (see table 3 ) showed that there is correlation between age and PERBEN, $r=.272, p<0.05$ (1tailed). Groenewald (2003) argue that land reform has traditionally had two objectives: equity and productivity. Food insecurity and the need for agriculture to contribute to development emphasise the need to maintain and improve productivity while improving equitability. Land must foster production and agriculture must attract good human material. Groenewald (2003) states that the main problem involves policy formulation and delivery necessary conditions include: A proper institutional framework involving all the relevant public and private bodies: the role and tasks of each should be clear, and also relationships between institutions. Proper fiscal planning is essential (Groenwald, 2003) possibly successful farmers must be selected and given special support, including extension and adult education.

\subsection{Knowledge, Support and Perceived benefits of Land Reform in South Africa}

Groenewald (2003) argue that land reform has traditionally had two objectives: equity and productivity as there is the need for agriculture to contribute to development emphasize the need to maintain and improve productivity while improving equitability. Land must raise production and agriculture must attract good human material.

Table 4: Zero order Correlations for the relationships between Knowland, Suppolar And Perben

\begin{tabular}{|ll|c|c|c|}
\hline & & Knowland & Suppolar & Perbern \\
\hline \multirow{2}{*}{ Knowland } & Pearson Correlation & 1 & .073 & $.260^{*}$ \\
& Sig. (2-tailed) & & .563 & .035 \\
\hline \multirow{2}{*}{ Suppolar } & Pearson Correlation & .073 & 1 & -.128 \\
& Sig. (2-tailed) & .563 & & .305 \\
\hline \multirow{2}{*}{ Perbern } & Pearson Correlation & $.260^{*}$ & -.128 & 1 \\
& Sig. (2-tailed) & .035 & .305 & \\
\hline
\end{tabular}

*. Correlation is significant at the 0.05 level (2-tailed).

Bivariate correlation on the relationships between three variables KNOWLAND, SUPPOLAR and PERBERN is shown in table 4. The result showed that There was a correlation between KNOWLAND and PERBEN, $r=.260, p<0.05$ (1-tailed). Fabbriciani (2007) outlined the three elements of the land reform programme to include; redistribution to bring equity to 
the land market, land restitution for victims of forced removals, and land tenure reform. There is thus a compelling case for a thorough review not only of land reform policy, but rural development and economic policies more generally, if they are truly to address the challenges of continuing poverty and inequality. This is only likely to occur, however, on the basis of a major mobilisation of the rural poor and landless in order to influence the policy-making process in a way that has not occurred in South Africa since 1994 (Lahiff, 2007). Rural people depend on farming for their livelihood; the case is that they control a little piece of land. They are hired as labours at the large farms where they earn low wages. Income will rise on rural communities once they have great control of the arable land. Land reform can contribute to job creation and income increases.

\section{Discussion}

Mansuri \& Rao (2013) argued that collective participation has two broad branches. The first is cohesion, the ability of a community to coordinate and to manage its own activities on matters that are quite independent of states and markets. The second is the ability of the community to represent its collective interests to the agents of the state and persuade the state to be more responsive to its needs. Another reason why participation of beneficiaries is important is that it can raise commitment to the project. There are various needs of the community that land reform will play an important role to achieve. For example, they want the roads, irrigation, electricity, potable water, education, health service, or agricultural technology and participation will make them support land reform and support the project with their positive attitudes. Finsterbusch (1987) argued that participation has more beneficial effects in the Third World countries. Therefore participation will become increasingly important as Third World countries develop and achieve the benefits of land reform.

The findings of this study shows that the population of Mtunzini both males and females are interested in land reform. The strong statistical adherence to most important questions eliciting responses on knowledge (mean $=3.05, \mathrm{SD}$ $=1.087$ ), support (mean $=3.11, S D=1.314$ ) and perceived benefits (mean $=3.14, D=1.201$ ) to land reform, indicated strong interests. The result of this study underscored the limitations of the willing seller willing buyer approach which inhibits the full negotiation power of the claimants thus hindering participation. Tilley (2004) showed that land reform stakeholders and the Department of Land Affairs were unreliable negotiating partners, because applicants do not have negotiating power on their own behalf and depend on department officials to finalize the transaction. This underscores the need for a more inclusive process that incorporates the participation of benefiting communities as a whole. Furthermore, Hall (2003) noted that since the beginning of land reform in the early 1990s, it has been surrounded by a lack of basic information arising from inadequate and often non-existent of monitoring and evaluation process. As the result from the present study showed, members of the community of Mtunzini are vaguely familiar with the land reform programme, having limited access to information about the claiming process. No doubt, this puts the possibility of the programme attaining its objectives in jeopardy. According to Fabbriciani (2007), the three core elements of the land reform programme are; to re redistribution to bring equity to the land market, land restitution for victims of forced removals, and land tenure reform. However, as the result of the present study show, the land reform process is a long way from meeting its objective as local community members perceive that the processs is slow in spite of the great demand for restitution among the larger segments of the population. For a variety of reasons that include different economic goals of land reform beneficiaries, poor planning, and lack of government support, most of the land purchased by group farms remained unutilized (Kepe \& Cousins, 2002). The success of land reform will make black people feel the sense of repatriation. However, this might not be achieved soon. Lahiff (2007) argued that most of the good quality land is sold by public auctions or private transactions that cause land reform beneficiaries to access only lower quality land. Consequently, a vast proportion of the productive land remains in the hands of the white people in South Africa. Land reform will not meet its objective unless land reform policy is restructured to favour white land owners and poor mass black people alike. Lahiff, (2007) argued that whilst white farmers are the major role players in the slow pace of land reform, it is the policy in place that is not strong enough to solve past injustices and economic concentration in the hands of a particular race group.as Greenberg (2002) argued the land reform in South Africa has been captured by elite interests.

The knowledge therefore about land reform plays an important role in the program because it is the basis upon which people derive their support for the programme. The result from the present study shows a positive correlation between knowledge and support for land reform. According to Holden (2008), the knowledge of land reform contributes in the process of land distribution in rural areas because when people have enough knowledge, about the law, they will be able to understand land reform from their traditional behaviour. The result from the present study showed that the people of Mtunzini both Black and Whites support for land reform. However the support they have is limited to the amount of knowledge they have about land reform. The support for land reform on its own shows that there is a gap in the lives of 
the people that have not yet been addressed, and that the restitution of land would possibly fill that gap. It is therefore imperative for the government to consult and carry along the views of the people at the grass root level, because regardless of the much support people have about land reform, the programme will not meet it objective unless all stakeholders are fully participating in process..

Gaventer \& Valderrama (1999) argued that though beneficiaries can participate as individuals, the results are greater if their contribution is through groups. The land reform programme then will not meet its objectives and prosper if the role players are at the government levels because even situations that people at grassroots level encounter on daily basis contribute in the creation of ideas that will make land reform faster. The result from this study showed that if traditional leaders are given full participation in land reform redistribution, the process will be better enhanced. This connotes that in the land reform policy and processes there are structures of the society that could be better involved in playing their roles. The participation of all structures will not only play an important role in the redistribution of land, but will also play a role in the management of beneficiaries' community development projects because the purpose is not only to redistribute land but also to make land productive. This productivity will be enhanced by when beneficiaries are given necessary skills and capacitation. In the case of shortages of agricultural skills the participation of all members of the community will alleviate that problem. Thomas (2013) argued that participation takes time, additional resources, and additional skills. However, this study argues that land reform has to come with the financial support to the beneficiaries. Financial support is important in that once the beneficiaries have land on their hands they must have financial support to sustain their projects for productivity. There must therefore be proper implementation of skills development programmes specifically in agriculture that will not only concentrate on farming strategies but also in understanding of trade and the knowledge of finances, because if the beneficiaries do not have these necessary skills their projects will collapse and land reform will not meet its objective.

In the rural areas people do not have enough knowledge about land reform; this portends the risk that the important information about the processes of land reform is known by the few elites of the community. As that is the case the benefits of land reform is possibly attained by those individuals or groups that have information. This underscores the need for participation of every individual in the community in the all processes of land reform because the poor people shall not only participate by supporting land reform but must also know the processes and potential benefits. It has been established here that the knowledge that people have determines their support for land reform. In addition, the support that people have for land reform comes from understanding land reform and perceiving the possibilities that it will prosper them. Therefore the participation of all structures of the community will also create knowledge about land reform and mechanisms in which it will prosper because cooperation is an important principle in that it recognizes the uniqueness of each member's participation (Duraiappah, Roddy \& Parry, 2005).

Nawaz (2013) argued that people who have both the right and duty to participate in solving their own problems, have greater responsibilities in assessing their needs, mobilizing local resources and suggesting new solutions as well as creating and maintaining local organizations. This implies that where the government have all powers of making policies, these policies may not be effective where they neglect the needs of the communities. Therefore the perceptions that people have concerning land reform will make a very big contribution on land reform, by providing ideas that the government may not have. If the people at the grassroots level have land on their hands it will be possible for them to mobilize resources necessary to make land productive. The analysis of the society is thus important in the drafting of land reform policy.

Martinussen (1997) argued that the too much involvement of the masses in decision making might hinder growth, because ordinary citizens lacked the foresight and imagination required to plan for the future. On the contrary however, this study argues that when people work for common goals, policies will succeed because knowledge will be shared and people will mobilize if they support the programme. Thus the involvement of all stakeholders will make land reform a possibility, and the involvement of everyone will mean everyone will benefit from the programme.

\section{Conclusion}

This study sought to investigate the level of knowledge and perceptions of the community members about land reform in South Africa. The results showed rural community members have marginal knowledge of land reform. Knowledge of land reform is however dependent on community members' social demographic characteristics. It was further shown that the people of Mtunzini support the land reform program. The people see the possibilities that land reform will provide benefits they need for community development. Most importantly however and in line with the central objective of the study, the results showed that community members' knowledge of land reform determine their support for land reform and their perceived achievable benefits from land reform. 
Land reform is aimed at alleviating the problem of inequality and landlessness. Thus participatory development approaches can be applied in all activities that need the variety of skill for it to prosper, as a means to development. The participatory development approach was utilized to better describe the contribution that can be made by the community members to the land reform programme. The result of the study showed that the involvement of the civil society in the decision making process will accelerate the pace of land reform and bring equity within restitution, because the public would have influenced the policy. The result contrasts with the willing seller willing buyer approach, which falls short of incorporating or empowering the people at grassroots level, leaving their abilities and capabilities hugely undermined. This is in spite of the fact that the people at the grassroots level are experiencing the issues of landlessness on daily basis as whilst their participation is being restricted.

The participatory development approach is thus central as a mechanism for recognition of the skills and ideas that people at grassroots level have that can be helpful on land reform. Participation does not require material means or high rank in the community to sustain livelihood. People who are landless are those that are the victims of dispossession. Participatory development encourages the involvement of everyone in order for the project to develop because when people use different skills in one project they will share ideas from different experiences and abilities. Consequently, the involvement of all members of the community will increase the chances of success of the land reform programme.

The moves from government towards civil society, and from social and project participation towards governance offer new spaces in which the concept of participation may also be expanded to one of citizenship, one which involves linking participation in the political, community and social spheres.

\section{Recommendations}

The results of this study shows that people at grassroots level know about land reform, thus this study recommends that there should be programmes that will seek to develop knowledge of the programme in terms of the policies and the processes of land reform. The knowledge people at the grassroots level have will enable them to device strategies they could implement in making land reform a reality. Although land reform is a national issue there should be decentralization of responsibilities to all structures of the society with traditional leaders as the first major role players in increasing the pace of land reform. South Africa is conducting land reform under willing seller willing buyer principle; this study has argued that this approach does not recognize the input that could be made by the civil society in making land reform a reality.

\section{References}

Bhengu L.E.E. (1999) The controversy of land reform: A case of Mpangisa Mid-Illovo. University of Zululand).

Brinkhoff T. (2013) Mtunzini Population. Retrieved from: www.citypopulation.de.

Duraiappah K. A., Roddy P., \& Parry J. (2005) Have Participatory Approaches Increased Capacities? International Institute for Suitable Development. Canada.

Fraser A. (2007) White farmers dealings with land reform in South Africa: Evidence from Northern Limpompo Province. University of Ireland. Ireland.

Greenberg S. (2010) Status report on land and agricultural policy in South Africa: Research Report 40. Institute for Poverty, Land and Agrarian Studies. University of the Western Cape, South Africa.

Groenewald A. (2003) Conditions for Successful Land Reform in Africa. Paper presented at Pre-IAAE Conference on African Agricultural Economics, Bloemfontein, South Africa, August 13-14, 2003. University of the Free State.

Holden S. (2008) From Being Property of Men to Becoming Equal Owner? Early Impacts of Land Registration and Certification on Women in Southern Ethiopia. Norwegian University of Life Science.

http://www.raosoft.com/samplesize.html).

Kepe T. (1999) The problem of defining 'community': Challenges for the land reform programme in rural South Africa. Development Southern Africa.

Lahiff E. (2007) 'Willing Buyer, Willing Seller': South Africa's Failed Experiment in Market-Led Agrarian Reform. Third World Quarterly pp. 1577-1597. Taylor and Francis.

Mupambwa G., Nekhwevha F.H. \& Ige K.D. (2012). The Integrated Development Plan and Women Empowerment in the Rural Eastern Cape Province of South Africa. International Journal of Social Science Tomorrow, 1(7): 1-16.

Mwatwara W. (2013) The Politics of Land Reform: comparative study of South Africa and Zimbabwe in the post 1994 era. Paper Presented at the conference on "Land Divided": Land and South African society in 2013, in comparative perspective, University of Cape Town, 2013.

Nawaz F. (2013) Power, Empowerment and Participatory Development: Conceptual Linkages. Open Journal of Social Research, 1 (2):26-30. 